\title{
Farmers' preference on the characteristics of improved variety and prospective lines of soybean seed in acidic dry-land (a case study in South Kalimantan and East Lampung)
}

\author{
Nila Prasetiaswati ${ }^{*}$, Dian Adi Anggraeni Elisabeth, Ruly Krisdiana, and Fachrur Rozi \\ Indonesian Legumes and Tuber Crops Research Institute (Iletri), Jalan Raya Kendalpayak Km 8 \\ Malang 65101, East Java, Indonesia
}

\begin{abstract}
National soybean consumption in 2018 was not in balance with its production. One of factors affecting soybean production is locationspecific improved varieties utilization. The research aimed to identify farmers' considerations in responding improved soybean varieties and prospective lines. The research was conducted in KP Taman Bogo, East Lampung and BP3T at Tambak Ulang, South Kalimantan. Data collected presented into tables. A descriptive analysis used by calculating means and percentage value. The results showed that crop height, seed shape, drought resistance, and fall resistance were the dominant considerations for East Lampung farmers. South Kalimantan farmers chose growth type, flowering age, harvest age, pod color, non-breaking pod, leaf shape, seed color, wilting symptoms, pests and diseases resistance, fall resistance, and ease of sale variables. Of the ten lines and four Iletri's improved soybean varieties, East Lampung farmers chose Grobogan for crop phisycal performance as priority I (37.9\%) and II Tgm/933 (24,2\%); while South Kalimantan farmers chose Tanggamus (23.3\%), Tgm/Anj-910 (26,7\%) and Tgm/Anj-933 lines (30\%). For seed characteristics, $51.7 \%$ of East Lampung farmers chose Grobogan as priority I, while South Kalimantan farmers chose Tgm/Anj-931 line $(30.0 \%)$. It is expected that by selecting location-specific improved varieties, farmers can increase soybean production, thereby increasing their income.
\end{abstract}

\section{Introduction}

National soybean consumption in Indonesia in 2016 reached 2.85 tons while its production was only 860 hundred tons. The national soybean balance sheet experienced a deficit of 1.99 million tons. The national soybean consumption in 2018 reached 3.05 million tons, which was not in balance with national soybean production of 864 thousand tons, a deficit of 2.19 million tons. The demand on soybean is escalating in 2021 to around 2.6 million tons and causing an increase of deficit into 2.24 million tons [1].

\footnotetext{
* Corresponding author: nila.balitkabi@gmail.com
} 
Acidic dry-land has the potential for agricultural expansion in terms of soybean cropping. This land is widely spread throughout Indonesia apart from Java, including Sumatera, Kalimantan, Sulawesi, Maluku, and Papua [2].

Based on the exploration land resource data on the scale of 1:1,000,000, the total area of dry-land reaching 148 million hectares is classified into 102.8 million hectares of acidic dryland and 45.2 million hectares of non-acidic dry-land [3]. The total acidic dry-land in Lampung and South Kalimantan are 2,650,413 hectares and 1,751,591 hectares, respectively [4]. Climate and precipitation that are vary causes the land to become acid due to intensive leaching [5].

One of factor that affect the production is the seed. The use of superior seeds, such as the new improved variety in agriculture, is essential in increasing production. The excellent variety as a product of technology is requisite for agricultural product improvement [6]. There had been \pm 87 of soybean seed varieties being produced until the year 2009 [7], and small number of these are adaptive being cultivated in the acidic land.

Cropping new soybean varieties tolerant to acidic land by applying various tests on different locations is essential in producing excellent varieties according to the land's characteristics. Various researches prove that location holds a significant effect on the growth and productivity of a particular variety [8].

Currently, the Indonesian Agency for Agricultural Research and Development or Balitbangtan has released five excellent soybean varieties adaptive to acidic dry-land, namely: Tanggamus, Nanti, Sibayak, Seulawah, and Ratai. Nevertheless, based on farmers' market demand, those varieties do not fully follow the requirement as the seeds are considered relatively small (compared to imported soybean), and/ or the color of the seeds is somewhat green [9]. Soybean seed size in acidic dry-land is smaller than in non-acidic land (rice field). On the other hand, farmers and industries made from soybeans prefer to use largeseed soybeans rather than small-seed soybeans, so that in addition to improving the yields, it is also necessary to improve seed size [10]. This research aims to identify soybean characteristics considering respondent farmers' in respond the prospective improved variety.

\section{Methodology}

The research was conducted in KP Taman Bogo, East Lampung and Indonesian Agency of Integrated Agricultural Research and Development or BP3T at Tambak Ulang, Tanah Laut, South Kalimantan. Respondents as sampling in this survey taking by purposive. This is because the characteristics of soybean farmers in dry-land are homogeneous. The respondents for each location were 30 farmers, so that total number of respondents was 60 farmers. Ten prospective lines of soybean, namely: (1) Tgm/Anj-933, (2) Tgm/Anj-931, (3) Tgm/Anj-910, (4) Tgm/Anj-932, (5) Tgm/Anj-909, (6) Tgm/Anj-991, (7) Tgm/Anj-957, (8) Tgm/Anj-908, (9) Tgm/Anj-995, (10) Tgm/Anj-919, and four improved soybean varieties, namely: (11) Tanggamus, (12) Anjasmoro, (13) Wilis, and (14) Grobogan were introduced to respondent farmers to be evaluated for soybean seeds preference.

Primary and secondary data were collected to answer the purpose of the study. The primary data were achieved through direct interview with the respondent farmers using a questionnaire. It includes: a) farmers' age; b) educational background; c) farming experience; d) the area of soybean cultivating land; e) soybean variety being used and its purposes; as well as soybean seeds preference. Meanwhile, the secondary data were collected from various related institutions, such as local agricultural agency or Dinas Pertanian, plantation seed supervision and certification agency or BPSB, and assessment institute of agricultural technology or BPTP, and other relevant literatures. The data analysis model collected on the field was then made into tables for more proper presentation. The type of this analysis is a descriptive analysis by calculating the means and percentage values. 


\section{Results and discussion}

\subsection{The farmers' characteristics of East Lampung and South Kalimantan}

Age and educational background are personal factors that affect the technology adoption process. Educational background is closely related to the farmers' behaviors, such as the decision-making skill in terms of agricultural business [11]. The age of respondent farmers, their income, and the ease of selling their harvest product affects the consideration in adopting new technology. With the increase of age, there is also an increase in avoiding risks and the downturn of interest on the long-term investment [12-13].

On average, the respondent farmers in East Lampung were in their productive age group with the average of 47.0 years old (in a range of 25-70 years old), while in South Kalimantan was around 37.0 (in a range of 20-60 years old). The educational background in both areas was quite high, as most farmers were graduated from senior high school to undergraduate degree. The evidence proves that farmers in both areas can take decisions and have very good work performance in the agricultural business [14].

Table 1. The farmers' characteristics of East Lampung and South Kalimantan.

\begin{tabular}{|c|c|c|}
\hline \multirow{2}{*}{ Farmers' characteristics } & \multicolumn{2}{|c|}{ Location } \\
\cline { 2 - 3 } & East Lampung & South Kalimantan \\
\hline Age (\%) & & 63.3 \\
\hline $15-19$ & 53.3 & 13.3 \\
\hline $20-40$ & 13.3 & 13.3 \\
\hline $41-60$ & 20.0 & 10.0 \\
\hline$>60$ & 13.3 & 33.3 \\
\hline Education (\%) & & 50.0 \\
\hline Primary school & 30.0 & 16.7 \\
\hline Junior high school & 43.3 & 0.0 \\
\hline Senior high school & 23.3 & $4-5$ \\
\hline Undergraduate degree & 3.3 & 1.4 \\
\hline Experience (year) & $1-2$ & \\
\hline Land tenure (ha) & 0.3 & \\
\hline
\end{tabular}

Having experiences in agricultural business is one of essential factors in supporting the success of agricultural business. The longer the experience is, the easier for the farmers to adopt new technology; thus, experience determines the farmers' agricultural skills [15]. Respondent farmers in Lampung only have 1 to 2 years of experience in the soybean farming with land tenure of 0.3 hectare on average with the help of the local agricultural agency or Dinas Pertanian. Only a small number of Lampung farmers cultivate soybean based on the difficulties on crop maintenance and marketing consideration. On the other hand, farmers in South Kalimantan have more experience, averagely 4.3 years with land tenure of 1.4 hectare. The land area has a positive effect on the application level of soybean production technology [16].

In South Kalimantan, land tenure by farmers is wider than that in Lampung, so the opportunity for soybean development is greater. In addition, the competition for land use in South Kalimantan is smaller, so it is easier for farmers to grow soybeans, while in Lampung the competition for land use is tighter because they compete with other food crops (cassava and other legumes). 


\subsection{The farmers' expectation towards soybean crop characteritics on field}

Based on the farmer's consideration and assessment of the technology performance in the field, all respondents prefer to the large-seed soybean. The favorable crop characteristics of farmers in both location, East Lampung and South Kalimantan are quite similar.

Respondent farmers in East Lampung chose the varieties based on high productivity $(100.0 \%)$, yellow seed color $(79.3 \%)$, brown pod color $(51.7 \%)$, determinate growing type (100.0\%), budding age 40-45 days $(55.2 \%)$, harvest age $85-90$ days $(48.3 \%)$, and roundshaped seeds $(86.2 \%)$. Further, $65.5 \%$ of farmers prefer tall crops, $37.9 \%$ of farmers chose medium-sized seeds and $62.1 \%$ prefer large-sized seeds, while $100.0 \%$ of farmers prefer crops that are resistant to fall and have many branches (Table 2).

Respondents in South Kalimantan chose high yielding soybeans (100.0\%), seeds with yellow skin color (93.3\%), determinate (bush) type crops $(100.0 \%)$, and old brown pods (70.0\%). Around $80 \%$ of farmers chose budding age 30-40 days and harvest age 75-68 days. $53.3 \%$ of farmers chose crops with medium height, $100.0 \%$ of farmers chose soybean crops resistant to fall, and $63.3 \%$ prefer crops with many branches (Table 2). Respondents in both locations indicated that they had similar preferences, including crops with high yields, yellow soybean seeds, dark brown pods, determinate type, medium to large round seeds, and crops that are resistant to fall. Soybean seeds with yellow color with size between medium to large are highly favored by traders in East Lampung, especially as the basic ingredient for making tempeh. Meanwhile, in South Kalimantan, medium-sized soybeans are used as ingredients for soy milk and bean sprouts, while the large seeds are used as the basic ingredient for tempeh. Farmers' preferences in the research location are similar to those of respondent farmers in Maros Regency, South Sulawesi, regarding the physical appearance of both seeds and crops. The preferable soybean crops are the ones that are resistant to fall, have large seeds and many branches, are expected to produce high production, yields are easy to sell, favored by traders and have higher prices than other varieties [17]. Kenyan farmers choose largeseeded soybean varieties for they have higher trade value and market prices [18-19].

Respondents from East Lampung prefer the budding age of 40-45 days and the harvesting age of 85-90 days. Farmers believed that a long harvest would result in high production. Meanwhile, South Kalimantan farmers prefer crops to bud and harvest early. It was conveyed that if soybean crops budding quickly, the harvest age would also be shorter. The budding age becomes the dominant factor for farmers because it is to suppress the main constraints such as limited water. Currently, the Grobogan and Anjasmoro varieties have been grown and are still being planted in that location. This finding proves that technology in the form of improved varieties is appropriate because it meets the criteria of technically usable and socially culturally acceptable [20].

In South Kalimantan, soybean farmers prefer the early-aged soybean varieties since soybeans are harvested at a young age and sold for snacks. Meanwhile, in Lampung, soybeans are harvested at an old age and sold as raw materials for the tofu and tempe industries. 
Table 2. Soybean characteristics expectation by respondent farmers for crops and seeds selection in East Lampung and South Kalimantan.

\begin{tabular}{|c|c|c|}
\hline \multirow{2}{*}{ Soybean characteristics } & \multicolumn{2}{|c|}{ Location } \\
\hline & East Lampung & South Kalimantan \\
\hline \multicolumn{3}{|l|}{ Production (\%) } \\
\hline High (2 ton/ha) & 100.0 & 100.0 \\
\hline Medium (1.7 ton/ha) & 0.0 & 0.0 \\
\hline \multicolumn{3}{|l|}{ Seeds color $(\%)$} \\
\hline Yellow & 79.3 & 93.3 \\
\hline Yellowish & 20.7 & 6.7 \\
\hline Green & 0.0 & 0.0 \\
\hline Black & 0.0 & 0.0 \\
\hline \multicolumn{3}{|l|}{ Old pods color $(\%)$} \\
\hline Brown & 51.7 & 70.0 \\
\hline Black & 48.3 & 30.0 \\
\hline \multicolumn{3}{|l|}{ Crop type $(\%)$} \\
\hline Determinate & 100.0 & 100.0 \\
\hline Semi-determinate & 0.0 & 0.0 \\
\hline Interdeterminate & 0.0 & 0.0 \\
\hline \multicolumn{3}{|l|}{ Budding age (\%) } \\
\hline $30-40$ days & 44.8 & 80.2 \\
\hline 40-45 days & 55.2 & 20.0 \\
\hline$>45$ days & 0.0 & 0.0 \\
\hline \multicolumn{3}{|l|}{ Harvest age (\%) } \\
\hline $75-80$ days & 20.7 & 100.0 \\
\hline $80-45$ days & 31.0 & 0.0 \\
\hline $85-90$ days & 48.3 & 0.0 \\
\hline$>90$ days & 0.0 & 0.0 \\
\hline \multicolumn{3}{|l|}{ Seeds shape (\%) } \\
\hline Ovale & 13.8 & 26.7 \\
\hline Round & 86.2 & 73.3 \\
\hline \multicolumn{3}{|l|}{ Crop height (\%) } \\
\hline High $(60 \mathrm{~cm})$ & 65.5 & 46.7 \\
\hline Medium $(45-50 \mathrm{~cm})$ & 34.5 & 53.3 \\
\hline Short $(<45 \mathrm{~cm})$ & 0.0 & 0.0 \\
\hline \multicolumn{3}{|l|}{ Seeds size $(\%)$} \\
\hline Large $(15-17 \mathrm{~g} / 100$ seeds $)$ & 62.1 & 63.3 \\
\hline Medium (10-14 g/ 100 seeds) & 37.9 & 36.7 \\
\hline Small $(<10 \mathrm{~g} / 100$ seeds $)$ & 0.0 & 0.0 \\
\hline \multicolumn{3}{|l|}{ Fall resistence $(\%)$} \\
\hline Resistence to fall & 100.0 & 100.0 \\
\hline Easy to fall & 0.0 & 0.0 \\
\hline \multicolumn{3}{|l|}{ Branches $(\%)$} \\
\hline Many & 100.0 & 63.3 \\
\hline A few & 0.0 & 36.7 \\
\hline
\end{tabular}

\subsection{The performance of farmers' preferences on the characteristics of soybean crops and seeds}

\subsubsection{Crop physical characteristics}

Farmers easily adopt improved varieties if they make a real contribution to increasing yield production. The productivity improvement program needs to be supported by the great 
yielding varieties tolerant of biotic and abiotic environmental stresses. The improved soybean varieties' performance showed that 30 respondents in East Lampung chose soybean crops with medium to high crop growth, sturdy stems, resistance to fall, early maturity, and many flowers, pods, and branches. The largest percentage of priority I (very preferable) and II was the Grobogan variety, respectively $37.9 \%$ and $27.6 \%$. Tgm/Anj-933 and Tgm/Anj-995 lines were the priority II, respectively $24.1 \%$ and $20.7 \%$. As the priority III, $27.6 \%$ of farmers prefer to Tgm/Anj-995 line and $20.7 \%$ chose the Willis variety. These findings indicate that if the Grobogan variety is not available at the location, the above lines are the substitute options (Table 3).

Respondents from South Kalimantan prefer short to medium soybean crops but with strong stems, resistance to fall, have many branches and pods. The largest percentage of priority I was Tanggamus variety $(23.3 \%)$; followed by Tgm/Anj-910 (16.7\%) and Tgm/Anj909 (16.7\%) lines. For the priority II, the largest percentage was Tgm/Anj-910 (26.7\%) and the priority III was, Tgm/Anj-933 and Tgm/Anj-910 lines (23.3\%).

Based on the results above, the farmers in East Lampung and South Kalimantan had different preferences on the physical characteristics of soybeans, and it appears that farmers always choose improved varieties. However, farmers also choose the prospective lines, which showed that the opportunity for developing high-yielding varieties of large-seed soybeans is very large for South Kalimantan and Lampung (Table 3).

\subsubsection{Seed physical characteristics}

Farmers' preferences for soybean size vary. Some prefer large-seed soybeans, other prefer the small or medium ones. This preference relates to soybean-based food products produced. Soybean size is one of the determinants of tempeh quality, especially the weight and volume and sensory properties. As for tofu products, the main variable that determines tofu quality is protein content of soybean seeds, especially globulin fraction affecting the tofu yield and texture [21]. Popular soybean products in today's society are fermented products such as tempeh, soy sauce, and tauco, and also non-fermented products such as tofu and soymilk. In East Lampung, the most common products from soybean are tempeh and tofu; therefore, traders and tofu artisans prefer yellow soybeans with round shape and medium to large-sized seeds. In Table 3, it can be seen that the respondent farmers chose Grobogan variety as priority I (51.7\%). The priority II and III were Tgm/Anj-995 and Tgm/Anj-991 lines at 24.1\%

In addition to tofu and tempeh, soymilk and bean sprouts are the soybean-based food products that commonly produced in South Kalimantan. These products require small, medium to large soybean seeds. Tempeh requires large-sized seeds; while tofu requires medium to large-sized seeds. As for soy milk and bean sprouts, they require small and medium-sized soybeans. However, farmers prefer medium and large soybean seeds, which are in demand by local tofu, tempeh, and bean sprouts food artisans and traders. The priority I from respondent farmers was Tgm/Anj-931 line (30.0\%). Tgm/Anj-931 line has a medium seed size and yellow color which is suitable for tofu, tempeh and bean sprouts; The priority II was Tgm/Anj-995 line (36.7\%). This line is preferable because the seeds are medium size, round shape and yellow, suitable for tofu, tempeh and bean sprouts. The largest percentage for the priority III was Tgm/Anj-991 line (33.3\%). This line is of medium seed size; oval shape and yellow.

Based on the above results, both in terms of crop and seed physical characteritics, the majority preference of respondent farmers in East Lampung was the Grobogan variety, and the next preference was on the Tgm/Anj-933 line. Meanwhile, in South Kalimantan, in terms of crop characteristics, the most farmers chose Tanggamus variety, which was acidic resistant. However, from seed characteristics, farmers chose Tgm/Anj-931 line. . 
Table 3. Percentage of farmers' priority for crop and seed physical characteristics of soybean improved varieties and prospective soybean lines.

\begin{tabular}{|c|c|c|c|c|}
\hline \multirow{3}{*}{ Priority } & \multicolumn{3}{|c|}{ Soybean improved varieties and prospective soybean lines } \\
\cline { 2 - 5 } & \multicolumn{2}{|c|}{ East Lampung } & \multicolumn{2}{c|}{ South Kalimantan } \\
\cline { 2 - 5 } & $\begin{array}{c}\text { Crop } \\
\text { characters }\end{array}$ & $\begin{array}{c}\text { Seed } \\
\text { characters }\end{array}$ & $\begin{array}{c}\text { Crop } \\
\text { characters }\end{array}$ & $\begin{array}{c}\text { Seed } \\
\text { characters }\end{array}$ \\
\hline \multirow{2}{*}{ Priority I } & $\begin{array}{c}\text { Grobogan } \\
(37,9 \%)\end{array}$ & $\begin{array}{c}\text { Grobogan } \\
(51,7 \%)\end{array}$ & $\begin{array}{c}\text { Tanggamus } \\
(23,1 \%)\end{array}$ & $\begin{array}{c}\text { Tgm/Anj-931 } \\
(30 \%)\end{array}$ \\
\hline \multirow{2}{*}{ Priority II } & $\begin{array}{c}\text { Tgm/Anj-933 } \\
(24,2 \%)\end{array}$ & $\begin{array}{c}\text { Tgm/Anj-995 } \\
(24,2 \%)\end{array}$ & $\begin{array}{c}\text { Tgm/Anj-910 } \\
(26,7 \%)\end{array}$ & $\begin{array}{c}\text { Tgm/Anj-995 } \\
(36,7 \%)\end{array}$ \\
\hline \multirow{2}{*}{ Priority III } & $\begin{array}{c}\text { Tgm/Anj-995 } \\
(27,6 \%)\end{array}$ & $\begin{array}{c}\text { Tgm/Anj-991 } \\
(24,2 \%)\end{array}$ & $\begin{array}{c}\text { Tgm/Anj-933 } \\
(30 \%)\end{array}$ & $\begin{array}{c}\text { Tgm/Anj-991 } \\
(33 \%)\end{array}$ \\
\hline
\end{tabular}

Note: Priority I: very preferable; Priority II: preferable; Priority III: less preferable

Number in parantheses shows the percentage of respondent farmer's preference

\section{Conclusions}

The first priority of soybean characteristics prefer by farmers in East Lampung and South Kalimantan are yield potential and large seeds. The second priorities for farmers in Lampung are number of branches and resistance to fall. While,farmers in South Kalimantan prefer early-aged and brown pod color soybean characteristics.

The potential improvements of the superior characteristics of soybean expected from improved varieties and prospective lines in South Kalimantan are Tanggamus variety, and also Tgm/Anj-995 and Tgm/Anj-991, and Tgm/Anj-931lines. Meanwhile, in East Lampung, farmers still prefer improved varieties of Grobogan instead of the prospective lines.

\section{References}

1. M. Ghulamahdi, Kebijakan harga kedelai dan perlindungan petani, in https://dpis.ipb.ac.id/kebijakan-harga-kedelai-dan-perlindungan-petani (2021)

2. A. A. Abdurachman, Dariah, A. Mulyani, Jurnal Litbang Pertanian 27, 43 (2008)

3. A. Mulyani, Hikmatullah, H. Subagyo, Karakteristik dan potensi tanah masam lahan kering di Indonesia, in Proceedings of Simposium Nasional Pendayagunaan Tanah Masam, Pusat Penelitian dan Pengembangan Tanah dan Agroklimat, Bogor, Indonesia (2004)

4. Puslitbangtanah, Atlas sumber daya tanah eksplorasi Indonesia. Skala 1: 1.000.000, in Pusat Penelitian Tanah dan Agroklimat, Bogor, Indonesia (2000)

5. H. Subagyo, N. Suharta, A. B. Iswanto, Tanah pertanian di Indonesia, in Sumber Daya Lahan Indonesia dan Pengelolaannya, Pusat Penelitian Tanah dan Agroklimat, Bogor, Indonesia (2000)

6. M. Asaad, S.S. Bananiek, Jurnal Pengkajian dan Pengembangan Teknologi Pertanian 3, 37 (2018)

7. D. Harnowo, J. S. Utomo, Sejarah, Tugas Pokok, dan Kinerja UPBS Agro Inovasi Akabi, in Badan Penelitian dan Pengembangan Pertanian, Pusat Penelitian dan Pengembangan Tanaman Pangan, Balai Penelitian Tanaman Aneka Kacang dan Umbi, Malang, Indonesia (2017)

8. F. Gurmu, H. Mohammad, G. Alemaw, African Crop Sci. J. 17, 87 (2009)

9. Subandi, IPTEK Tanaman Pangan 2, 12 (2007)

10. H Kuswantor, Darman, M. Arsyad, Purwantoro, Buletin Palawija 25, 1 (2013)

11. K. S. Farid, N. Z. Tanny, P. K. Sarma, J. Bangladesh Agril. Univ. 13, 291 (2015) 
12. T. B. Udima, Z. Jincai, O. S. Mensah, A. E. Caesar, Journal of Economics and Sustainable Development 8, 137 (2017)

13. S. Liu, P. Zhang, B. Marley, W. Liu, Agriculture 9, 188 (2019)

14. Soekartawi, Prinsip dasar ekonomi pertanian, in Teori dan Aplikasi, Rajawali Press, Jakarta, Indonesia (1989)

15. S. Murdy, Peranan KUPEM dalam meningkatkan produksi kentang di Kabupaten Kerinci, in http://onlinejournal.unja.ac.id/index/php/jseb/a rticle.downlod/299/214 (2012)

16. E. Rachmawati, E. Djuwendah, Jurnal Sosiohumaniora 10, 31 (2008)

17. N. Prasetiaswati, M. M. Adie, Tingkat penerimaan petani terhadap calon varietas kedelai berumur genjah (75 hari) dan hasil tinggi di Kabupaten Maros, in Proceedings of Pengembangan Ekonomi Kreatif Berbasis Komoditas Pertanian di Indonesia, Program Studi Agribisnis Fakultas Pertanian, Universitas Sebelas Maret (UNS), Surakarta, Indonesia (2013)

18. J. Chianu, B. Vanlauwe, J. Mukalama, A. Adesina, N. Sanginga, African Journal Agriculture Research 1, 143 (2006)

19. J. M. Mahasi, J. Mukalama, R. C. Mursoy, P. Mbehero, B. Vanlauwe, A sustainable approach to increase soybean production in western Kenya, in Proceedings of 10th African Crop Science Conference, 10-13 October 2011, Maputo, Mozambique, Africa (2006)

20. B. Saragih, Peranan teknologi tepat guna dalam pembangunan sistem agribisnis kerakyatan dan berkelanjutan, in Proceedings of Seminar II Teknologi Tepat Guna, Bandung, Indonesia (2000)

21. E. Ginting, S. S. Antarlina, S. Widowati, Jurnal Litbang Pertanian 28, 73 (2009) 